\title{
Pearls \& Oy-sters: Hickam's Dictum in Genetic Myopathies
}

\author{
When a Proven Pathogenic Mutation Does Not Explain the Phenotype
}

Daniel Sánchez-Tejerina, MD, * Luísa Panadés-de Oliveira, MD, ${ }^{*}$ Miguel A. Martín, PhD,

María I. Álvarez-Mora, PhD, Aurelio Hernández-Lain, PhD, and Cristina Domínguez-González, PhD

Neurology ${ }^{\circledR}$ 2021;96:1007-1009. doi:10.1212/WNL.0000000000012000

Correspondence

Dr. Panadés-de Oliveira

lupanades@gmail.com

\section{Pearls}

- Exercise intolerance is the most common phenotype in McArdle disease. Fixed weakness can be present in advanced ages, mainly affecting the shoulder girdle.

- ANO5 patients may present with a wide spectrum phenotype, including limb-girdle dystrophies, distal myopathies, and asymptomatic or mild symptomatic hyperCKemia. A characteristic radiologic pattern, involving the posterior compartment of the thigh, soleus, and medial gastrocnemius muscles in the legs, may assist in the genetic diagnosis of this entity.

\section{Oy-sters}

- Consider the coexistence of genetic conditions, particularly among patients with a history of consanguinity.

- Although fixed muscle weakness may be present in patients with McArdle disease, in the majority of cases, it is mild to moderate and associated or preceded by a history of exerciserelated symptoms.

- The presence of subsarcolemmal vacuoles that may contain periodic acid-Schiff (PAS)-positive glycogen and the absence of histochemical staining for myophosphorylase are hallmarks of McArdle disease on muscle biopsy. However, severe dystrophic changes are rare and should raise the suspicion of an additional concomitant myopathy.

A 67-year-old woman, born to consanguineous parents, was referred to our Neuromuscular National Reference Center with the diagnosis of McArdle disease made at age 58. She first noticed difficulties in climbing stairs and standing up from a sitting position in her 40s, which progressed over 10 years when she lost independent ambulation. She denied any history of exercise intolerance or episodes of rhabdomyolysis or myoglobinuria. She did not have symptoms of bulbar or extraocular musculature weakness, nor did she report cardiac or respiratory issues.

Initial laboratory tests showed elevated creatine kinase (CK) levels (range 1049-1269 U/L) and normal lactate levels. ECG showed a first-degree atrioventricular block, with a normal echocardiogram. Given the progressive proximal weakness and hyperCKemia, a muscle biopsy was performed and showed subsarcolemmal accumulation of glycogen (PAS-positive vacuoles) and myophosphorylase deficiency, but also striking dystrophic changes (figure). Sanger sequencing of the PYGM gene (NM_005609.3) identified the c.13_14del (p.Leu5ValfsTer22) frameshift variant in homozygosity, previously associated with McArdle disease (HGMD accession number: CD066398; ClinVar variation ID: 371064).

\footnotetext{
*These authors contributed equally to this work.
}

From the Neuromuscular Disorders Unit (C.D.-G.), Department of Neurology (D.S.-T., L.P., C.D.-G.), Laboratory of Mitochondrial Diseases, Department of Biochemistry, Instituto de Investigación (M.A.M.), and Departments of Clinical Genetics (M.I.Á.-M.) and Pathology (Neuropathology) (A.H.-L.), Hospital Universitario 12 de Octubre; Centro de Investigación Biomédica en Red de Enfermedades Raras (CIBERER) (M.A.M., C.D.-G.), Instituto de Salud Carlos III, Madrid; Department of Biochemistry and Molecular Genetics (M.I.Á.-M.), Hospital Clínic of Barcelona; and Hospital 12 de Octubre Research Institute (imas12) (C.D.-G.), Madrid, Spain.

Go to Neurology.org/N for full disclosures. Funding information and disclosures deemed relevant by the authors, if any, are provided at the end of the article. 

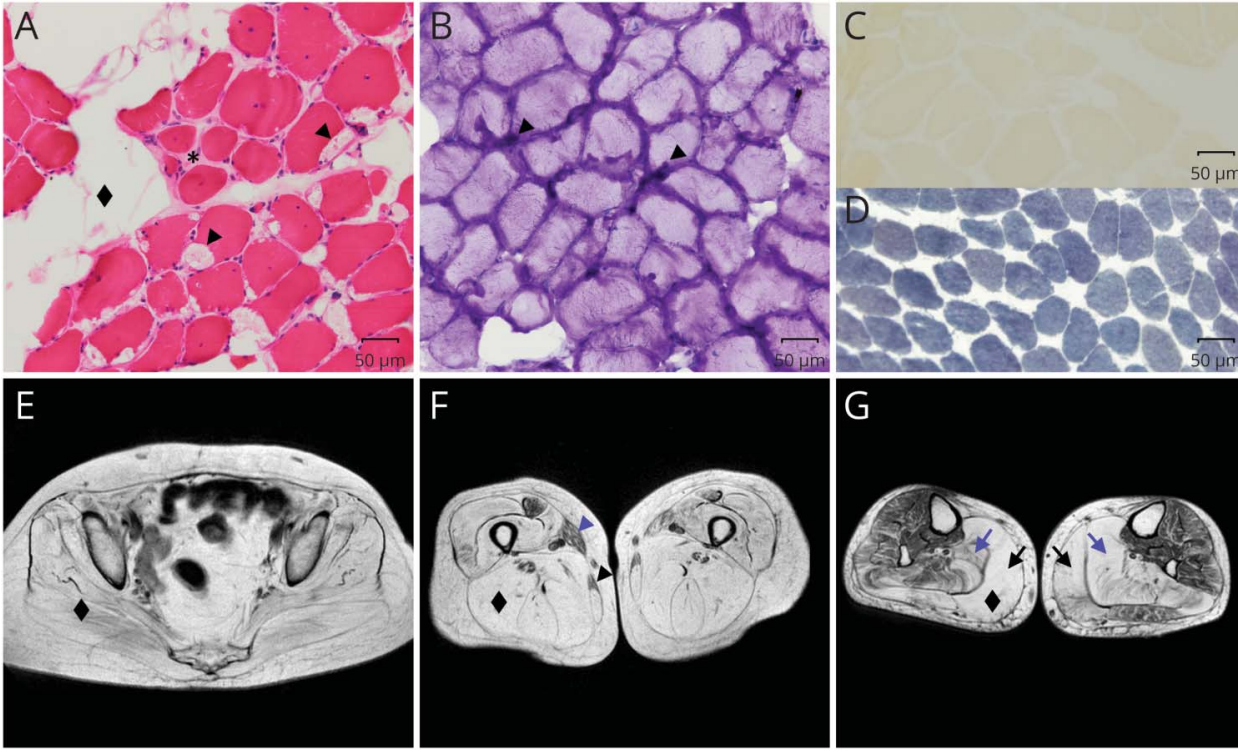

(A) Hematoxylin \& eosin (H\&E) staining shows changes in fiber size with endomysial fibrosis $\left(^{*}\right)$ and fatty replacement ( $\bullet$ ). (A, B) H\&E staining shows subsarcolemmal vacuoles with excess glycogen storage, determined by periodic acid-Schiff staining (arrowheads). (C, patient; D, control) Histochemical staining reveals the absence of myophosphorylase activity. (E, F) Axial T1-weighted MRI shows extensive muscular fatty infiltration $(\downarrow)$ at pelvic and thigh levels, sparing gracilis (blue arrowhead) and sartorius (black arrowhead) muscles. (G) Axial T1-weighted image at leg level shows a predominant involvement of medial gastrocnemius (black arrows) and soleus muscles (blue arrows), a characteristic radiologic pattern of limb-girdle muscular dystrophy 12 .
Neurologic examination revealed symmetric proximal muscular weakness and bilateral calf hypertrophy. Manual muscle strength testing revealed the following Medical Research Council scores: shoulder abduction 4/5, elbow flexion 4-/5, elbow extension $4+/ 5$, distal upper limbs musculature $5 / 5$, hip abduction, adduction, and flexion $2 / 5$, knee flexion and extension $4 / 5$, distal lower limbs musculature $5 / 5$. The patient was not able to rise from a chair and independent ambulation was not possible, requiring bilateral support. The rest of the neurologic examination was unremarkable, and reflexes were normal. A nonischemic exercise forearm test showed a flat curve for both venous lactate and ammonia, probably due to insufficient effort during the test.

After review of clinical and paraclinical features, an overlapping muscle dystrophy was suspected. A muscle MRI was performed (figure), confirming extensive muscular fatty infiltration, which involved almost the whole pelvic and thigh musculature, sparing solely gracilis and sartorius muscles. At the leg level, it showed a predominant involvement of medial gastrocnemius and soleus.

Subsequently, next-generation sequencing of a targeted panel of 202 genes related to muscular disorders was performed, and an additional homozygous pathogenic mutation was identified in the ANO5 gene (NM_213599.2: c.191dup, p.Asn64Lysfs* 15 ), associated with limb-girdle muscular dystrophy 12 (LGMDR12), ${ }^{1}$ formally called LGMD2L. The patient was finally diagnosed with double genetic trouble, harboring proven pathogenic mutations homozygosis in 2 different genes. The latter is probably the main cause that explains the clinical phenotype.

\section{Discussion}

Approximately 1,875 protein-coding genes are known to be linked to autosomal recessive disorders, according to the Clinical Genomic Database of the National Human Genome Research Institute. ${ }^{2}$ It has been estimated that every individual is a carrier of more than 20 of these disorders or traits. ${ }^{3}$ The probability of sharing carrier status for a rare autosomal recessive disease is considerably higher for related couples than for unrelated individuals. In this report, the patient, born to consanguineous parents, was found to have 2 recessive conditions, which we briefly review.

McArdle disease is the most common glycogen storage disease. It is an autosomal recessive condition caused by mutations in the myophosphorylase gene (PYGM) that encodes the skeletal muscle-specific isoform of phosphorylase and leads to blocked muscle glycogenolysis. Age at onset is frequently in the first decade of life, but the diagnosis is often delayed, and many patients are diagnosed after early adulthood. ${ }^{4,5}$ The usual presentation is exercise intolerance that consists of premature muscle fatigue, contractures, pain, and episodes of myoglobinuria, triggered by short intense exercise or by dynamic aerobic exercises involving large muscle mass (e.g., stair-climbing, running, or walking very fast). A characteristic feature of the condition is the so-called second wind phenomenon, considered pathognomonic for the disease. It is described by patients as relief of symptoms triggered by the onset of exertion, which appears about 10 minutes after starting the exercise, and allows them to resume physical activity. Persistent hyperCKemia is present in the majority of patients. ${ }^{5}$ 
Recessive mutations in the ANO5 gene are associated with muscular diseases named anoctaminopathies. Patients may present with proximal or distal fixed weakness or isolated persistent hyperCKemia. ${ }^{6}$ Calf hypertrophy is a relatively common sign of this condition. ${ }^{7}$ Muscle MRI may reveal typical signs, with preferential involvement of adductor and gastrocnemius muscles. ${ }^{8}$

In the case we report, the patient was initially diagnosed with McArdle disease based on the evidence of myophosphorylase deficiency in the muscle biopsy, which prompted the performance of a targeted PYGM genetic analysis. A muscle biopsy was performed prior to a forearm exercise test because the reported symptoms did not suggest a metabolic muscle disorder. Fixed muscle weakness occurs in approximately $20 \%-30 \%$ of affected individuals with McArdle disease, but it is normally preceded by a history of exercise-related symptoms. It is more likely to involve proximal muscles and is more common in individuals of advanced age. ${ }^{4,9}$ In the literature, there are only a few reports of patients diagnosed in later adulthood with a phenotype of fixed weakness as the sole clinical manifestation. ${ }^{10}$ The cause of the fixed weakness in McArdle disease and its phenotype heterogeneity remains unclear. ${ }^{4}$ To date, no genotype-phenotype correlation has been described. ${ }^{5,9}$

Regarding complementary tests, muscle pathology may show some degenerating or necrotic fibers, accompanied by regeneration, but the most consistent finding is PAS-positive subsarcolemmal vacuoles. The presence, in this case, of intense dystrophic changes in the muscle biopsy led, therefore, to the suspicion of another concomitant myopathy. Muscle MRI showed extensive fatty infiltration. Little is known about radiologic features in McArdle disease, and there are sporadic studies reporting fatty degeneration involving proximal muscles in patients with fixed weakness or advanced age. ${ }^{9}$ Therefore, it was necessary to rule out an associated limbgirdle muscular dystrophy in this case. A genetic analysis confirmed a concomitant anoctaminopathy, which better correlates with the patient's clinical picture.

We highlight the importance of carefully evaluating the entire clinical picture. The clinical features should outweigh the complementary tests to guide the definitive diagnosis. It is also important to remember that the coexistence of genetic conditions is possible, particularly among patients with a history of consanguinity. If complementary findings, including genetic results, do not explain the patient's clinical manifestations, the investigation should continue until it leads to a proper answer.

\section{Study Funding}

This work was partially funded by a grant to Dr. M.A. Martin from the Spanish Instituto de Salud Carlos III, ISCIII PI15/
00431, and Comunidad de Madrid, Spain, B2017/BMD3721, and FEDER Funding Program from the European Union.

\section{Disclosure}

The authors report no disclosures relevant to the manuscript. Go to Neurology.org/N for full disclosures.

\begin{tabular}{|c|c|c|}
\hline Name & Location & Contribution \\
\hline $\begin{array}{l}\text { Daniel } \\
\text { Sánchez- } \\
\text { Tejerina, MD }\end{array}$ & $\begin{array}{l}\text { Department of Neurology, } \\
\text { Hospital Universitario } 12 \\
\text { de Octubre, Madrid, Spain }\end{array}$ & $\begin{array}{l}\text { Acquisition of data and } \\
\text { drafting of the original } \\
\text { manuscript }\end{array}$ \\
\hline $\begin{array}{l}\text { Luísa } \\
\text { Panadés-de } \\
\text { Oliveira, MD }\end{array}$ & $\begin{array}{l}\text { Department of Neurology, } \\
\text { Hospital Universitario } 12 \\
\text { de Octubre, Madrid, Spain }\end{array}$ & $\begin{array}{l}\text { Acquisition of data and } \\
\text { drafting of the original } \\
\text { manuscript }\end{array}$ \\
\hline $\begin{array}{l}\text { Miguel A. } \\
\text { Martín, PhD }\end{array}$ & $\begin{array}{l}\text { Laboratory of } \\
\text { Mitochondrial Diseases, } \\
\text { Department of } \\
\text { Biochemistry, Instituto de } \\
\text { Investigación Hospital } 12 \\
\text { de Octubre, Madrid (i+12), } \\
\text { Spain }\end{array}$ & $\begin{array}{l}\text { Analysis and } \\
\text { interpretation of genetic } \\
\text { studies }\end{array}$ \\
\hline $\begin{array}{l}\text { María I. } \\
\text { Álvarez- } \\
\text { Mora, PhD }\end{array}$ & $\begin{array}{l}\text { Department of Clinical } \\
\text { Genetics, Hospital } \\
\text { Universitario } 12 \text { de } \\
\text { Octubre, Madrid, Spain }\end{array}$ & $\begin{array}{l}\text { Analysis and } \\
\text { interpretation of genetic } \\
\text { studies }\end{array}$ \\
\hline $\begin{array}{l}\text { Aurelio } \\
\text { Hernández- } \\
\text { Lain, PhD }\end{array}$ & $\begin{array}{l}\text { Department of Pathology } \\
\text { (Neuropathology), Hospital } \\
\text { Universitario } 12 \text { de } \\
\text { Octubre, Madrid, Spain }\end{array}$ & $\begin{array}{l}\text { Preparation of images and } \\
\text { interpretation of } \\
\text { neuropathologic studies }\end{array}$ \\
\hline $\begin{array}{l}\text { Cristina } \\
\text { Domínguez- } \\
\text { González, } \\
\text { PhD }\end{array}$ & $\begin{array}{l}\text { Neuromuscular Disorders } \\
\text { Unit, Department of } \\
\text { Neurology, Hospital } \\
\text { Universitario } 12 \text { de } \\
\text { Octubre, Madrid, Spain }\end{array}$ & $\begin{array}{l}\text { History and examination } \\
\text { of patient, critical revision } \\
\text { of the manuscript for } \\
\text { important intellectual } \\
\text { content }\end{array}$ \\
\hline
\end{tabular}

\section{References}

1. Bolduc V, Marlow G, Boycott KM, et al. Recessive mutations in the putative calciumactivated chloride channel anoctamin 5 cause proximal LGMD2L and distal MMD3 muscular dystrophies. Am J Hum Genet 2010;86:213-221.

2. Solomon BD, Nguyen A-D, Bear KA, Wolfsberg TG. Clinical genomic database. Proc Natl Acad Sci 2013;110:9851-9855.

3. The 1000 Genomes Project Consortium. A map of human genome variation from population-scale sequencing. Nature 2010;467:1061-1073.

4. Lucia A, Nogales-Gadea G, Pérez M, Martín MA, Andreu AL, Arenas J. McArdle disease: what do neurologists need to know? Nat Rev Neurol 2008;4:568-577.

5. Santalla A, Nogales-Gadea G, Encinar AB, et al. Genotypic and phenotypic features of all Spanish patients with McArdle disease: a 2016 update. BMC Genomics 2017;18:819.

6. Wicklund MP, Kissel JT. The limb-girdle muscular dystrophies. Neurol Clin 2014;32: 729-749.

7. Silva AMS, Coimbra-Neto AR, Souza PVS, et al. Clinical and molecular findings in a cohort of ANO5-related myopathy. Ann Clin Transl Neurol 2019;6:1225-1238.

8. Sarkozy A, Deschauer M, Carlier RY, et al. Muscle MRI findings in limb girdle muscular dystrophy type 2L. Neuromuscul Disord 2012;22:S122-S129.

9. Nadaj-Pakleza AA, Vincitorio CM, Laforêt P, et al. Permanent muscle weakness in McArdle disease. Muscle Nerve 2009;40:350-357.

10. Chéraud C, Froissart R, Lannes B, Echaniz-Laguna A. Novel variant in the PYGM gene causing late-onset limb-girdle myopathy, ptosis, and camptocormia: new PYGM variant. Muscle Nerve 2018;57:157-160. 


\section{Neurology}

\section{Pearls \& Oy-sters: Hickam's Dictum in Genetic Myopathies: When a Proven Pathogenic Mutation Does Not Explain the Phenotype}

Daniel Sánchez-Tejerina, Luísa Panadés-de Oliveira, Miguel A. Martín, et al. Neurology 2021;96;1007-1009 Published Online before print April 9, 2021

DOI 10.1212/WNL.0000000000012000

\section{This information is current as of April 9, 2021}

\section{Updated Information \& Services}

\section{References}

Subspecialty Collections

Permissions \& Licensing

Reprints including high resolution figures, can be found at: http://n.neurology.org/content/96/21/1007.full

This article cites 10 articles, 1 of which you can access for free at: http://n.neurology.org/content/96/21/1007.full\#ref-list-1

This article, along with others on similar topics, appears in the following collection(s):

\section{All Genetics}

http://n.neurology.org/cgi/collection/all_genetics

Muscle disease

http://n.neurology.org/cgi/collection/muscle_disease

Information about reproducing this article in parts (figures,tables) or in its entirety can be found online at:

http://www.neurology.org/about/about_the_journal\#permissions

Information about ordering reprints can be found online:

http://n.neurology.org/subscribers/advertise

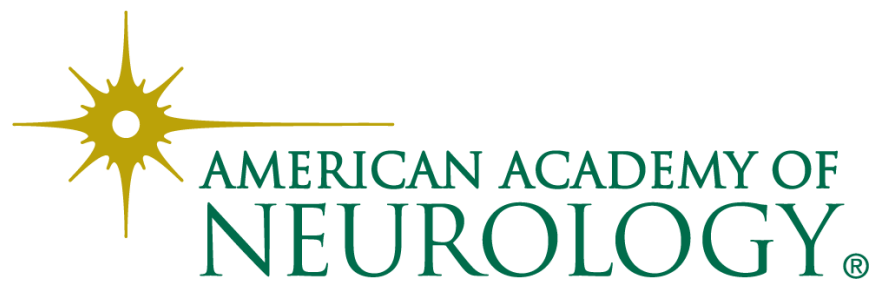

